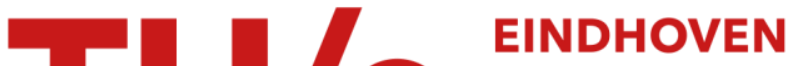 UNIVERSITY OF TECHNOLOGY
}

\section{A novel wearable vest for tracking pulmonary congestion in acutely decompensated heart failure : pilot study}

\section{Citation for published version (APA):}

Cuba Gyllensten, I., Gastelurrutia, P., Riistama, J., Aarts, R. M., Nunez, J., Lupon, J., \& Bayes-Genis, A. (2014). A novel wearable vest for tracking pulmonary congestion in acutely decompensated heart failure : pilot study. International Journal of Cardiology, 177, 199-201. https://doi.org/10.1016/j.ijcard.2014.09.041

DOI:

10.1016/j.ijcard.2014.09.041

Document status and date:

Published: 01/01/2014

\section{Document Version:}

Publisher's PDF, also known as Version of Record (includes final page, issue and volume numbers)

\section{Please check the document version of this publication:}

- A submitted manuscript is the version of the article upon submission and before peer-review. There can be important differences between the submitted version and the official published version of record. People interested in the research are advised to contact the author for the final version of the publication, or visit the $\mathrm{DOI}$ to the publisher's website.

- The final author version and the galley proof are versions of the publication after peer review.

- The final published version features the final layout of the paper including the volume, issue and page numbers.

Link to publication

\section{General rights}

Copyright and moral rights for the publications made accessible in the public portal are retained by the authors and/or other copyright owners and it is a condition of accessing publications that users recognise and abide by the legal requirements associated with these rights.

- Users may download and print one copy of any publication from the public portal for the purpose of private study or research.

- You may not further distribute the material or use it for any profit-making activity or commercial gain

- You may freely distribute the URL identifying the publication in the public portal.

If the publication is distributed under the terms of Article 25fa of the Dutch Copyright Act, indicated by the "Taverne" license above, please follow below link for the End User Agreement:

www.tue.nl/taverne

Take down policy

If you believe that this document breaches copyright please contact us at:

openaccess@tue.nl

providing details and we will investigate your claim. 


\title{
A novel wearable vest for tracking pulmonary congestion in acutely decompensated heart failure
}

\author{
Illapha Cuba-Gyllensten a,b,*,1, Paloma Gastelurrutia ${ }^{\text {c,1 }}$, Jarno Riistama ${ }^{\text {b }}$, Ronald Aarts ${ }^{\text {a,b }}$, Julio Nuñez ${ }^{\text {d }}$, \\ Josep Lupon e,f, Antoni Bayes-Genis c,e,f,** \\ a Signal Processing Systems, Eindhoven University of Technology, The Netherlands \\ b Philips Research, Eindhoven, The Netherlands \\ c ICREC Research Program, Fundació Institut d'Investigació en Ciències de la Salut Germans Trias i Pujol (IGTP), Badalona, Spain \\ d Cardiology Service, Hospital Clínico Universitario de Valencia, Spain \\ e Cardiology Service, Hospital Universitari Germans Trias i Pujol, Badalona, Spain \\ ${ }^{\mathrm{f}}$ Department of Medicine, Universitat Autònoma de Barcelona, Barcelona, Spain
}

\section{A R T I C L E I N F O}

Article history:

Received 31 July 2014

Accepted 16 September 2014

Available online 28 September 2014

Keywords:

Bioelectrical bioimpedance analysis

Heart failure

Pulmonary congestion

Heart failure (HF) is a clinical syndrome characterized by signs of congestion [1]. Milder forms of pulmonary congestion can be difficult for clinicians to evaluate, thus there is a need for new objective, noninvasive, and without adverse effects approaches to its assessment. Bioimpedance can be used to evaluate tissue hydration [2], as increased fluids lead to less resistance to electric currents, thus lower measurement values, and vice versa. In this study, we investigated a novel system consisting of a wearable vest with four textile electrodes mounted in two pairs on a flexible belt, ensuring that the inter-electrode distance is fixed (Fig. 1.A). The aim was to assess whether the bioimpedance data captured could track clinical improvements in the signs and symptoms of congestion due to acutely decompensated HF (ADHF).

Twenty patients admitted to the cardiology ward for ADHF were included (mean age $74.7 \pm 9.5,45 \%$ ischaemic, LVEF $37.0 \pm 12.5$ ). All

\footnotetext{
* Correspondence to: I. Cuba-Gyllensten, TU/E-Department of Electrical Engineering Signal Processing Systems-PT 3.20, PO Box 513, 5600MB Eindhoven, The Netherlands. Tel.: + 31618984204 .

** Correspondence to: A. Bayes-Genis, Department of Medicine, UAB, Hospital Universitari Germans Trias i Pujol Carretera del Canyet s/n 08916 Badalona, Spain. Tel.: +34 934978915; fax: + 34934978939 .

E-mail addresses: illapha@gmail.com (I. Cuba-Gyllensten), abayesgenis@gmail.com (A. Bayes-Genis).

${ }^{1}$ Both authors equally contributed to this work.
}

signed the informed consent and had no exclusion criteria (comorbidities that would limit life expectancy for the following year; a thoracic implanted device (other than Medtronic); acute ST-elevated myocardial infarction; severe chronic obstructive pulmonary disease; severe aortic valve regurgitation; aortic aneurysm; intra- and extra-cardiac shunts; acute pulmonary embolism; pregnant or breastfeeding; and history of heart transplant or listed for heart transplant). First measurement was made $<48 \mathrm{~h}$ from admission to the hospital. Mean duration of hospital admission was $9.4 \pm 4.3$ days.

Blood sampling and echocardiography were performed during index admission. Bioimpedance (taken in a semi-recumbent position with the ward couch lifted to $30^{\circ}$ for $5 \mathrm{~min}$ ) and weight measurement were made on the inclusion day, the three subsequent days, and at discharge, together with an assessment of the New York Heart Association (NYHA) functional class and a clinician-assessed HF severity score (HFSS) based on Framingham congestion criteria [3] to assess HF decompensation [4, 5]. The study was reviewed and approved by the Hospital Ethics Committee.

The device measures sixteen different frequencies, from $10 \mathrm{kHz}$ to $1 \mathrm{MHz}$, distributed logarithmically and a nonstandard one-lead ECG. The four cole [6] were fitted to the measured bioimpedance spectra [7, 8]: $Z=R_{\infty}-\frac{R_{\infty}-R_{0}}{1+\left(j \frac{f}{f_{c}}\right)^{\alpha}}$ where $R_{0}$ reflects extracellular fluids, $R_{\infty}$ reflects intracellular fluids, $f_{c}$ is the tissue relaxation time, and $\alpha$ reflects tissue heterogeneity. Changes in $R_{0}$ were used to find correlations against standard markers of fluid change, congestion, and disease severity (weight, HFSS, and NYHA functional class, respectively). Pearson's correlation coefficient was used in a one-tailed hypothesis test, where a lower relative $R_{0}$ would reflect a worse clinical scenario. Furthermore, correlations against the absolute bioimpedance value were done with the presenting state congestion, as measured by values of NT-proBNP and HFSS. A significance level of 0.05 was assumed throughout.

Table 1 shows serial changes in clinical (HFSS, NYHA functional class, and weight) and bioimpedance $\left(R_{0}\right)$ data during hospital admission. Upon discharge, $95 \%$ of the patients were in NYHA functional class I-II and $90 \%$ had reduced HFSS to values of clinical stability (HFSS $\leq 2$ ). $R_{0}$ improved from admission to discharge in $90 \%$ of patients (Fig. 1.B for 

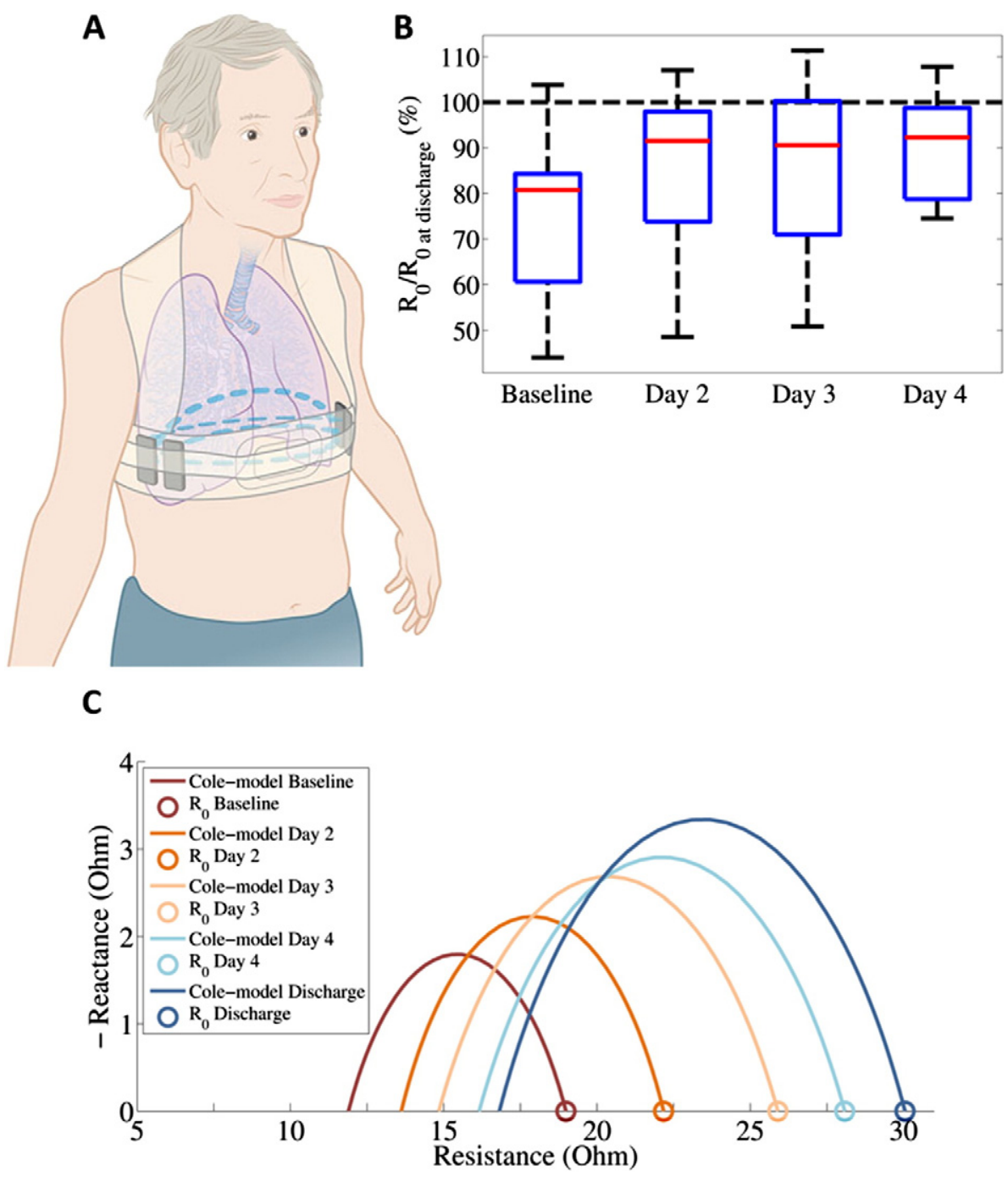

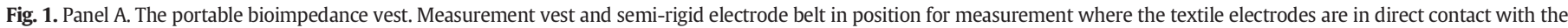

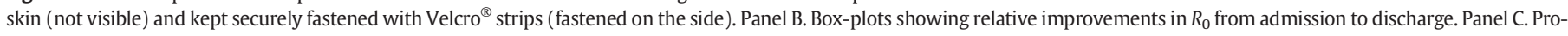
gression of Cole-Cole model for a representative patient during treatment. $R_{0}$ values are circled on the x-axis.

bloxplots and Fig. 1.C for a representative example of $R_{0}$ changes during hospitalization). The biggest change occurred on the first day, with subsequent smaller improvements thereafter. On day 3, almost threequarters of the patients were at least $85 \%$ of their discharge bioimpedance. Daily fluid levels during hospitalization tracked by weight reduction until discharge, correlated well with relative $R_{0}$ changes $(r=-0.830, p<0.001)$, as did changes in clinical congestion level, as determined by the HFSS $(r=-0.537, p<0.001)$. Significant correlations were also found between bioimpedance and other routine parameters of HF severity, such as $\operatorname{LVEF}(r=0.450, p=0.047)$ and NT-proBNP levels $(r=-0.41, p=0.038)$.

Since absolute bioimpedance is known to exhibit high individual variability, a sequential feature search using a naïve Bayesian model, indicated that a combination of variables was more discriminative than using absolute $R_{0}$ alone. Those variables were the difference in $R_{0}$ compared to an estimated dry lung (linear regression model based on the

Table 1

Changes in clinical and bioimpedance data from study enrolment to hospital discharge

\begin{tabular}{|c|c|c|c|c|c|}
\hline & Baseline & Day 2 & Day 3 & Day 4 & Discharge \\
\hline HFSS & $4.08 \pm 1.51^{\text {*** }}$ & $\begin{array}{l}2.1 \pm 1.70 \\
p=0.07\end{array}$ & $1.29 \pm 0.75$ n.s. & $1.4 \pm 1.38^{* *}$ & $0.55 \pm 0.67$ \\
\hline NYHA & II: 1, III: 5, IV: $14^{* * *}$ & II: 5 , III: 12, IV: $3^{*}$ & II: 9, III: 8 n.s. & II: 9, III: $7^{*}$ & I: 1 , II: 18 , III: 1 \\
\hline$\Delta$ Weight (kg) & $3.79 \pm 3.38^{* *}$ & $2.45 \pm 2.62^{*}$ & $\begin{array}{l}1.94 \pm 1.84 \\
p=0.06\end{array}$ & $1.75 \pm 1.80^{*}$ & 0 \\
\hline$\Delta R_{0}(\mathrm{Ohm})$ & $-7.71 \pm 5.49^{* * *}$ & $\begin{array}{l}-4.76 \pm 5.74 \\
p=0.06\end{array}$ & $-3.76 \pm 5.02$ n.s. & $-2.96 \pm 3.51^{* *}$ & 0 \\
\hline
\end{tabular}

Paired $t$-tests were performed between subsequent days to determine whether the observed changes were significant.

HFSS, heart failure severity score; NYHA, New York Heart Association class; $\Delta$, difference to discharge.

$* p<0.05$.

$* * \quad p<0.01$.

*** $p<0.001$ 
morphological parameters of fat mass [9] and chest circumferences in healthy controls), heart rate, and the ratio of extra- to intracellular fluids $\left(R_{0}\right.$ to $\left.R_{\infty}\right)$. The combination of these variables addresses body composition and morphology aspects, along with fluid distribution, which improved the identification of days with clinical decompensation (HFSS > 2). The resulting AUC was 0.76, as estimated by leave-patientout cross validation.

This pilot study showed the ability of this new device to track recompensation during therapy for ADHF at a cardiac ward as seen in the strong agreement with fluid loss (weight changes). This is in line with results from implantable bioimpedance devices [10], but our study suggests slightly higher correlations, which could be explained because the presented device targets both lungs and uses a spectroscopic approach to estimate fluids.

The device described in this paper has several new advantages: It is a noninvasive and easy to use device; thus, it could be worn in a home setting as a tool for disease management to prevent readmission. It uses textile electrodes that do not harm the skin and a vest that is worn as a normal garment at the time of measurement keeping the electrodes in the same position each time. It can transmit data, so that the patient and doctor can be in different locations but still in contact. Limitations in our study are: some specific body types may need to have specific adjustments in the vest and belt to fit them properly. The number of participants is small, but similar in size to other studies that assessed recompensation via other bioimpedance techniques [10]. And the potential interaction between implantable devices and the bioimpedance vest that slowed down enrolment (see exclusion criteria). At present, it has been tested against the Medtronic InSync Sentry ${ }^{\circledR}$ device and no interference was detected.

Future studies are required to confirm whether clinical decision making in ADHF might benefit from this noninvasive, easy-to-use bioimpedance vest. They will also be required to test the ability of the proposed device to determine the risk of events after hospital discharge.

\section{Authors' contributions}

Study concept and design: Gastelurrutia, Riistama and Bayes-Genis. Acquisition of data: Gastelurrutia and Lupón.

Analysis and interpretation of data: Cuba-Gyllensten, Gastelurutia, Riistama, Lupón, and Bayes-Genis.

Drafting of the manuscript: Cuba-Gyllensten, and Gastelurutia.

Critical revision of the manuscript for important intellectual content:

Cuba-Gyllensten, Gastelurutia, Riistama, Aarts, Lupón, Nuñez, and Bayes-Genis.

Statistical analysis: Cuba-Gyllensten and Riistama.

Study supervision: Riistama and Bayes-Genis.

Recruitment and treatment: Gastelurrutia and Lupón.

Final approval of the version to be published: Cuba-Gyllensten,

Gastelurutia, Riistama, Aarts, Lupón, Nuñez, and Bayes-Genis.

\section{Conflict of interest}

I. Cuba-Gyllensten: PhD student at Philips Research.

P. Gastelurrutia: none

J. Riistama: Researcher at Philips Research.

R. Aarts: Researcher at Philips Research.

J. Lupón: none.

J. Nuñez: none.

A. Bayes-Genis: none.

\section{Financial disclosures}

I. Cuba-Gyllensten: PhD student at Philips Research, EU Marie Curie Network iCareNet under grant number 264738.

P. Gastelurrutia: Redes Temáticas de Investigación Cooperativa en Salud (RETICS): Red Cardiovascular [RD12/0042/0047] and Red de Terapia Celular-TerCel [RD12/0019/0029], Ministerio de Economía y Competitividad (Juan de la Cierva, JCI-2012-14025).

J. Riistama: Researcher at Philips Research.

R. Aarts: Researcher at Philips Research.

J. Lupón: none.

J. Nuñez: none.

A. Bayes-Genis: none.

\section{References}

[1] McMurray JJV, Adamopoulos S, Anker SD, Auricchio A, Böhm M, Dickstein K, et al. ESC Guidelines for the diagnosis and treatment of acute and chronic heart failure 2012 The Task Force for the Diagnosis and Treatment of Acute and Chronic Heart Failure 2012 of the European Society of Cardiology. Developed in collaboration with the Heart Failure Association (HFA) of the ESC. Eur Heart J 2012;33:1787-847.

[2] Martinsen OG, Grimnes S. Bioimpedance and bioelectricity basics. Academic Press; 2011.

[3] Ho KKL, Pinsky JL, Kannel WB, Levy D. The epidemiology of heart failure: the Framingham study. J Am Coll Cardiol 1993;22:A6-A13.

[4] Pascual-Figal DA. Domingo M, Casas T, et al. Usefulness of clinical and NT-proBNP monitoring for prognostic guidance in destabilized heart failure outpatients. Eur Heart J 2008;29:1011-8.

[5] Gastelurrutia P, Nescolarde L, Rosell-Ferrer J, Domingo M, Ribas N, Bayes-Genis A. Bioelectrical impedance vector analysis (BIVA) in stable and non-stable heart failure patients: a pilot study. Int J Cardiol 2011;146:262-4.

[6] Cole KS, Cole RH. Dispersion and absorption in dielectrics I. Alternating current characteristics. J Chem Phys 1941:9:341-51.

[7] Kun DS, Peura RA. Selection of measurement frequencies for optimal extraction of tissue impedance model parameters. Med Biol Eng Comput 1999;37:699-703.

[8] Buendia R, Gil-Pita R, Seoane F. Cole parameter estimation from the modulus of the electrical bioimpeadance for assessment of body composition. A full spectroscopy approach. J Electr Bioimpedance 2011:2 [Available at: http://bada.hb.se/handle/ 2320/9430. Accessed January 31, 2013].

[9] Durnin JVGA, Womersley J. Body fat assessed from total body density and its estimation from skinfold thickness: measurements on 481 men and women aged from 16 to 72 years. Br J Nutr 1974;32:77-97.

[10] Whellan DJ, Droogan CJ, Fitzpatrick J, et al. Change in intrathoracic impedance measures during acute decompensated heart failure admission: results from the diagnostic data for discharge in heart failure patients (3D-HF) pilot study. J Card Fail 2012;18:107-12. 